Emerging Community Noise Reduction Approaches

\author{
Edmane Envia
}

Glenn Research Center, Cleveland, Ohio 


\section{NASA STI Program . . . in Profile}

Since its founding, NASA has been dedicated to the advancement of aeronautics and space science. The NASA Scientific and Technical Information (STI) program plays a key part in helping NASA maintain this important role.

The NASA STI Program operates under the auspices of the Agency Chief Information Officer. It collects, organizes, provides for archiving, and disseminates NASA's STI. The NASA STI program provides access to the NASA Aeronautics and Space Database and its public interface, the NASA Technical Reports Server, thus providing one of the largest collections of aeronautical and space science STI in the world. Results are published in both non-NASA channels and by NASA in the NASA STI Report Series, which includes the following report types:

- TECHNICAL PUBLICATION. Reports of completed research or a major significant phase of research that present the results of NASA programs and include extensive data or theoretical analysis. Includes compilations of significant scientific and technical data and information deemed to be of continuing reference value. NASA counterpart of peer-reviewed formal professional papers but has less stringent limitations on manuscript length and extent of graphic presentations.

- TECHNICAL MEMORANDUM. Scientific and technical findings that are preliminary or of specialized interest, e.g., quick release reports, working papers, and bibliographies that contain minimal annotation. Does not contain extensive analysis.

- CONTRACTOR REPORT. Scientific and technical findings by NASA-sponsored contractors and grantees.
- CONFERENCE PUBLICATION. Collected papers from scientific and technical conferences, symposia, seminars, or other meetings sponsored or cosponsored by NASA.

- SPECIAL PUBLICATION. Scientific, technical, or historical information from NASA programs, projects, and missions, often concerned with subjects having substantial public interest.

- TECHNICAL TRANSLATION. Englishlanguage translations of foreign scientific and technical material pertinent to NASA's mission.

Specialized services also include creating custom thesauri, building customized databases, organizing and publishing research results.

For more information about the NASA STI program, see the following:

- Access the NASA STI program home page at http://www.sti.nasa.gov

- E-mail your question via the Internet to help@ sti.nasa.gov

- Fax your question to the NASA STI Help Desk at $443-757-5803$

- Telephone the NASA STI Help Desk at 443-757-5802

- Write to: NASA Center for AeroSpace Information (CASI) 7115 Standard Drive Hanover, MD 21076-1320 
NASA/TM-2012-217248

AIAA-2011-3532

\section{Emerging Community Noise Reduction Approaches}

Edmane Envia

Glenn Research Center, Cleveland, Ohio

Prepared for the

3rd Atmospheric and Space Environments Conference

sponsored by the American Institute of Aeronautics and Astronautics

Honolulu, Hawaii, June 27-30, 2011

National Aeronautics and

Space Administration

Glenn Research Center

Cleveland, Ohio 44135

February 2012 


\section{Acknowledgments}

The NASA Subsonic Fixed Wing Project (SFW) of the Fundamental Aeronautics Program and the Environmentally Responsible Aviation (ERA) Project of the Integrated Systems Research Program have funded the work described herein.

Trade names and trademarks are used in this report for identification only. Their usage does not constitute an official endorsement, either expressed or implied, by the National Aeronautics and Space Administration.

This work was sponsored by the Fundamental Aeronautics Program at the NASA Glenn Research Center.

Level of Review: This material has been technically reviewed by technical management.

Available from

NASA Center for Aerospace Information 7115 Standard Drive

Hanover, MD 21076-1320
National Technical Information Service 5301 Shawnee Road Alexandria, VA 22312

Available electronically at http://www.sti.nasa.gov 


\title{
Emerging Community Noise Reduction Approaches
}

\author{
Edmane Envia \\ National Aeronautics and Space Administration \\ Glenn Research Center \\ Cleveland, Ohio 44135
}

\begin{abstract}
An overview of the current NASA research portfolio in the area of aircraft noise reduction is presented. The emphasis of the research described herein is on meeting the aggressive near- and mid-term national goals for reducing aircraft noise emissions, which NASA internal studies have shown to be feasible using noise reduction technologies currently being developed in-house or in partnership with NASA's industry and academic partners. While NASA has an active research effort in airframe noise reduction, this overview focuses on propulsion noise reduction only.
\end{abstract}

\section{Introduction}

Reducing aircraft noise emissions is an important part of the ongoing efforts to mitigate the impact of commercial aviation on the environment. The anticipated growth of the commercial air traffic in the next two decades (forecast (Ref. 1) shown in Fig. 1) calls for the development of low-noise aircraft that can offset the projected increase in the community noise exposure. To address this challenge, NASA is pursuing aggressive aircraft noise reduction goals as part of a comprehensive set of national aeronautics goals shown in Table 1. The environmental goals can be traced to the National Aeronautics Research and Development Plan, which was approved in December of 2007 (Ref. 2). The designations "N+1," "N+2," and " $\mathrm{N}+3$ " denote three successive aircraft generations beyond the current one in service today. NASA is conducting research across all three aircraft generations.

Clearly, meeting these noise goals requires significant reductions in the level of noise emissions from future aircraft compared to aircraft flying today. To highlight the magnitude of the challenge, Figure 2 shows the $\mathrm{N}+1$ and $\mathrm{N}+2$ noise goals in relation to the measured average noise level margin for a number of representative past and present generation commercial aircraft. Margin is the difference between the noise level that an aircraft generates at a given certification point and the level of allowable noise set by the noise regulation at that point, which is a function of the aircraft weight. Note that, since the national noise goals are expressed in terms of the cumulative margin (i.e., the sum of the margins at approach, flyover, and lateral certification points), to plot them on this graph, the average margin was taken to be one third of the cumulative margin.

The dramatic change required to meet these goals is the motivation for the aircraft noise research that NASA has been conducting over the last five years. In fact, the Subsonic Fixed Wing (SFW) Project and, more recently, the Environmentally Responsible Aviation (ERA) Project have been funding fundamental and system level research in low-noise aircraft concepts and noise reduction technologies that could meet these aggressive goals for the future subsonic transport aircraft. ${ }^{1}$ Ultimately, the main objective of NASA's aircraft noise reduction research is to provide a portfolio of low-noise technologies that do not compromise the other performance aspects of an aircraft.

An early outcome of this research campaign was two detailed NASA system noise studies on the feasibility of the $\mathrm{N}+1$ and $\mathrm{N}+2$ noise goals incorporating technologies currently being developed at NASA. In the first study, described in Reference 3, it is shown that a single aisle aircraft (see Fig. 3(a)) comparable to the Boeing 737-800, with advanced technology engines, could achieve a cumulative noise

\footnotetext{
${ }^{1}$ The SFW Project is part of the Fundamentals Aeronautics Program and the ERA Project is part of the Integrated Systems Research Program.
} 
margin that is 29 EPNdB below Stage 4. This means that it should be possible to close the gap with the $\mathrm{N}+1$ noise goal with additional improvements in technology. Finally, it should be noted that this airplane was designed as a noise-optimized solution in the design trade space.

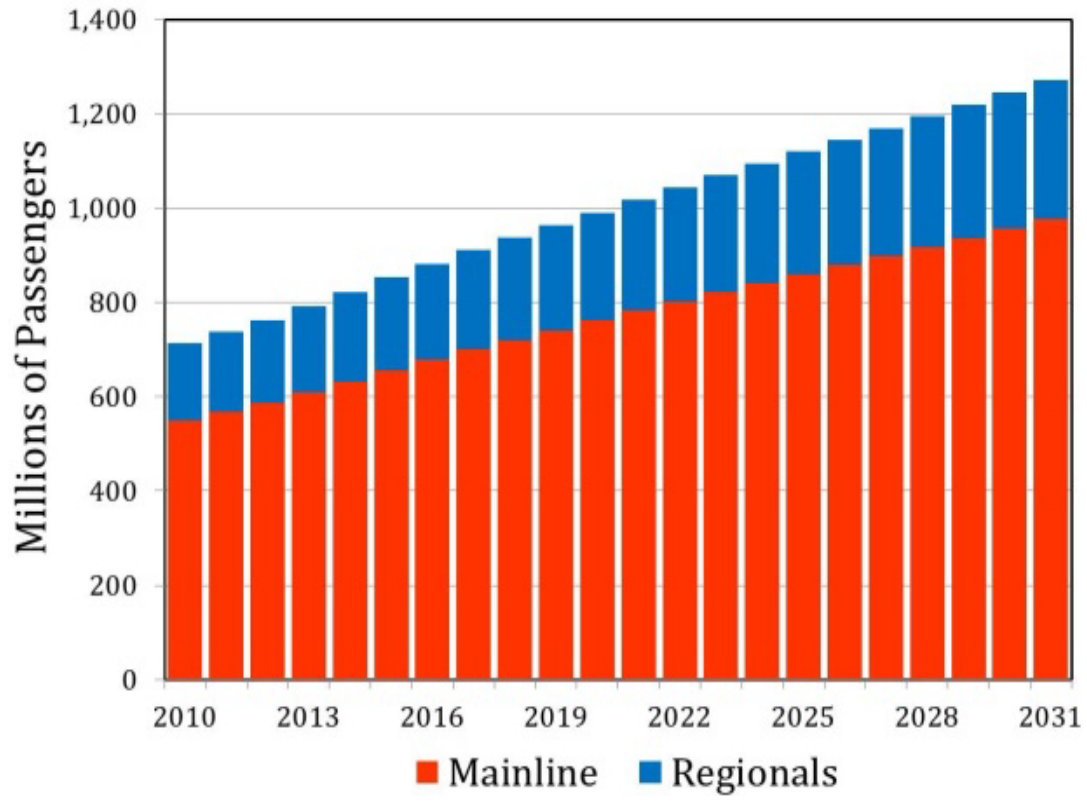

Figure 1.-U.S. Commercial Air Carriers-System Enplanements: Fiscal Years 2010 to 2031.

TABLE 1.-U.S. NATIONAL AERONAUTICS GOALS FOR SUBSONIC TRANSPORT AIRCRAFT

\begin{tabular}{|l|c|c|c|}
\hline \multirow{2}{*}{\multicolumn{1}{c|}{ Technology benefits $^{\mathrm{a}}$}} & \multicolumn{3}{|c|}{$\begin{array}{c}\text { Technology generations } \\
\text { (technology readiness level: 4 to 6) }\end{array}$} \\
\cline { 2 - 4 } & $\mathrm{N}+1(2015)$ & $\mathrm{N}+2\left(2020^{\mathrm{b}}\right)$ & $\mathrm{N}+3(2025)$ \\
\hline $\begin{array}{l}\text { Noise } \\
\text { (cumulative margin rel. to Stage 4) }\end{array}$ & $-32 \mathrm{~dB}$ & $-42 \mathrm{~dB}$ & $-71 \mathrm{~dB}$ \\
\hline $\begin{array}{l}\text { LTO NO } \\
\text { (rel. to CAEP 6) }\end{array}$ & $-60 \%$ & $-75 \%$ & $-80 \%$ \\
\hline $\begin{array}{l}\text { Cruise NO } \text { emissions } \\
\text { (rel. to 2005 best in class) }\end{array}$ & $-55 \%$ & $-70 \%$ & $-80 \%$ \\
\hline $\begin{array}{l}\text { Aircraft fuel/energy consumption } \\
\text { (rel. to 2005 best in class) }\end{array}$ & $-33 \%$ & $-50 \%$ & $-60 \%$ \\
\hline
\end{tabular}

${ }^{a}$ Projected benefits once technologies are matured and implemented by industry. Benefits vary by vehicle size. $\mathrm{N}+1$ and $\mathrm{N}+3$ values are referenced to a 737-800 with CFM56-7B engines; $\mathrm{N}+2$ values are referenced to a 777-200 with GE90 engines.

b ERA's time-phased approach includes advancing "long-pole” technologies to TRL 6 by 2015.

${ }^{\mathrm{c}} \mathrm{CO}_{2}$ emission benefits depend on life-cycle $\mathrm{CO}_{2 \mathrm{e}}$ per $\mathrm{MJ}$ for fuel and/or energy source used. 


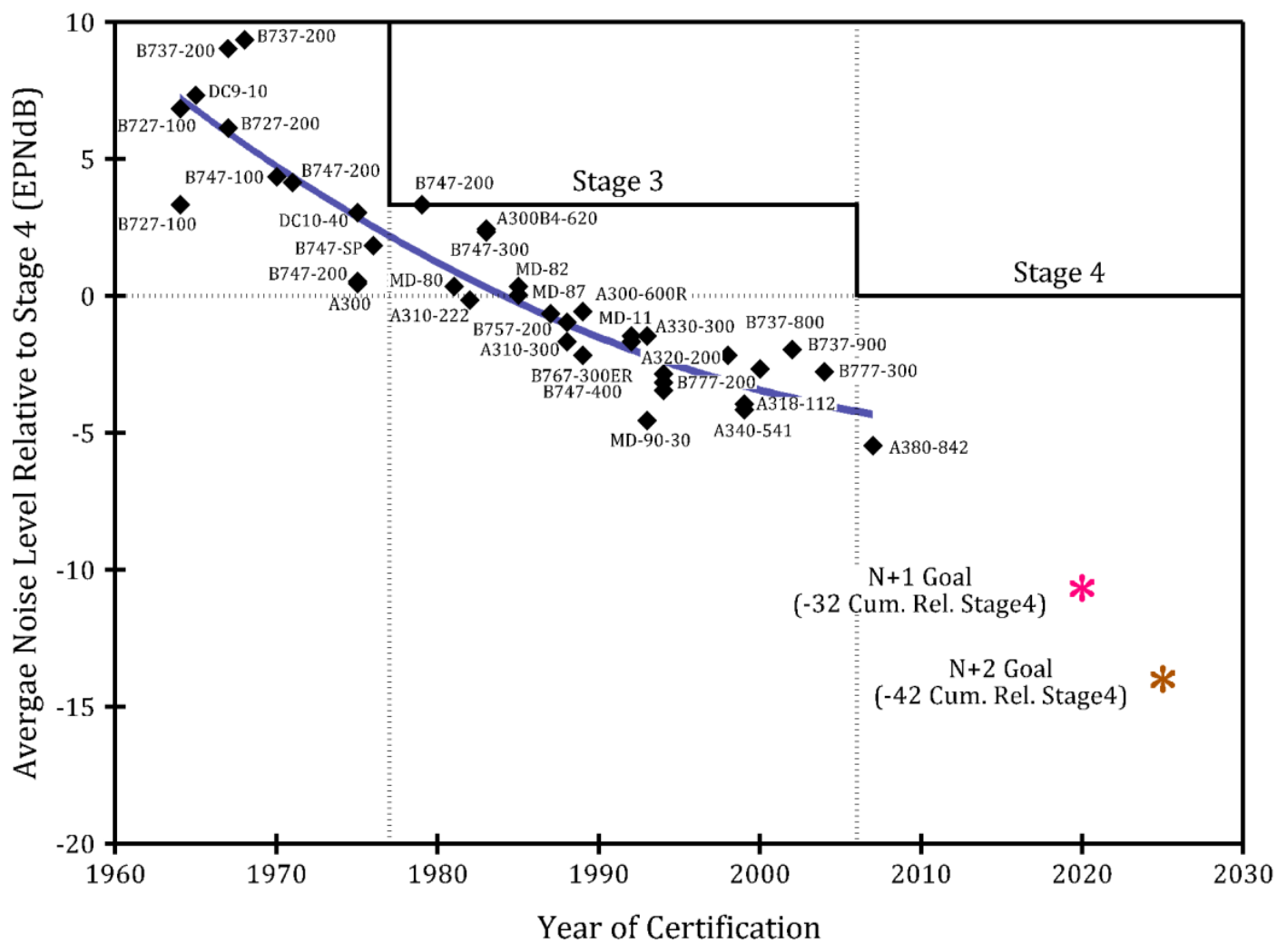

Figure 2.-Change in commercial aircraft noise level as function of time. Noise margins for only a few representative aircraft in various classes are plotted. The trend line is for illustrative purposes and is only meant to show the general direction of change. The $\mathrm{N}+1$ and $\mathrm{N}+2$ noise goals are also plotted by assuming that the average margin is one third of the cumulative margin.

In the second study, summarized in References 4 and 5, a detailed noise assessment of a twin-engine hybrid wing body aircraft (see Fig. 3(b)) showed that such a plane could achieve the N+2 noise goal with a cumulative noise margin that is 42.4 EPNdB below Stage 4. About half of this is attributable to the basic low-noise design of the hybrid wing body airframe with baseline engines and the rest is associated with the add-on technologies and advantageous propulsion airframe integration. This airplane was assumed to have the same engines and was sized for the same mission as the Boeing 777. The fact that the engines considered in the study are conventional, current generation engines suggests that an unconventional configuration like the hybrid wing body introduces a new paradigm in the way quiet aircraft of the future could be designed.

Feasibility of the $\mathrm{N}+3$ noise goal was addressed as part of studies funded by the SFW Project and carried out by teams of industry and academic partners who were asked to address simultaneously all $\mathrm{N}+3$ environmental and performance goals listed in Table 1 (Refs. 6 to 10). None of these studies produced an aircraft concept that could meet the $\mathrm{N}+3$ noise goal, but many interesting ideas were generated that could provide guidance for future work. An example of an $\mathrm{N}+3$ aircraft concept developed under these studies is dubbed "double-bubble" which was produced by a team led by MIT (see Fig. 3(c)). This aircraft is comparable to the Boeing 737-800 and is predicted to achieve a cumulative noise margin of $60 \mathrm{EPNdB}$ below Stage 4 . Clearly, more research is necessary to close the gap with the $\mathrm{N}+3$ noise goal. It should be noted that a previous study, conducted by the Cambridge-MIT Institute, produced the conceptual design for an aircraft called SAX-40, which was predicted to achieve a cumulative noise margin of $75 \mathrm{EPNdB}$ below Stage 4 (Ref. 11). However, this was achieved by ignoring some of the current certification rules like glide slope at approach and the landing threshold. 


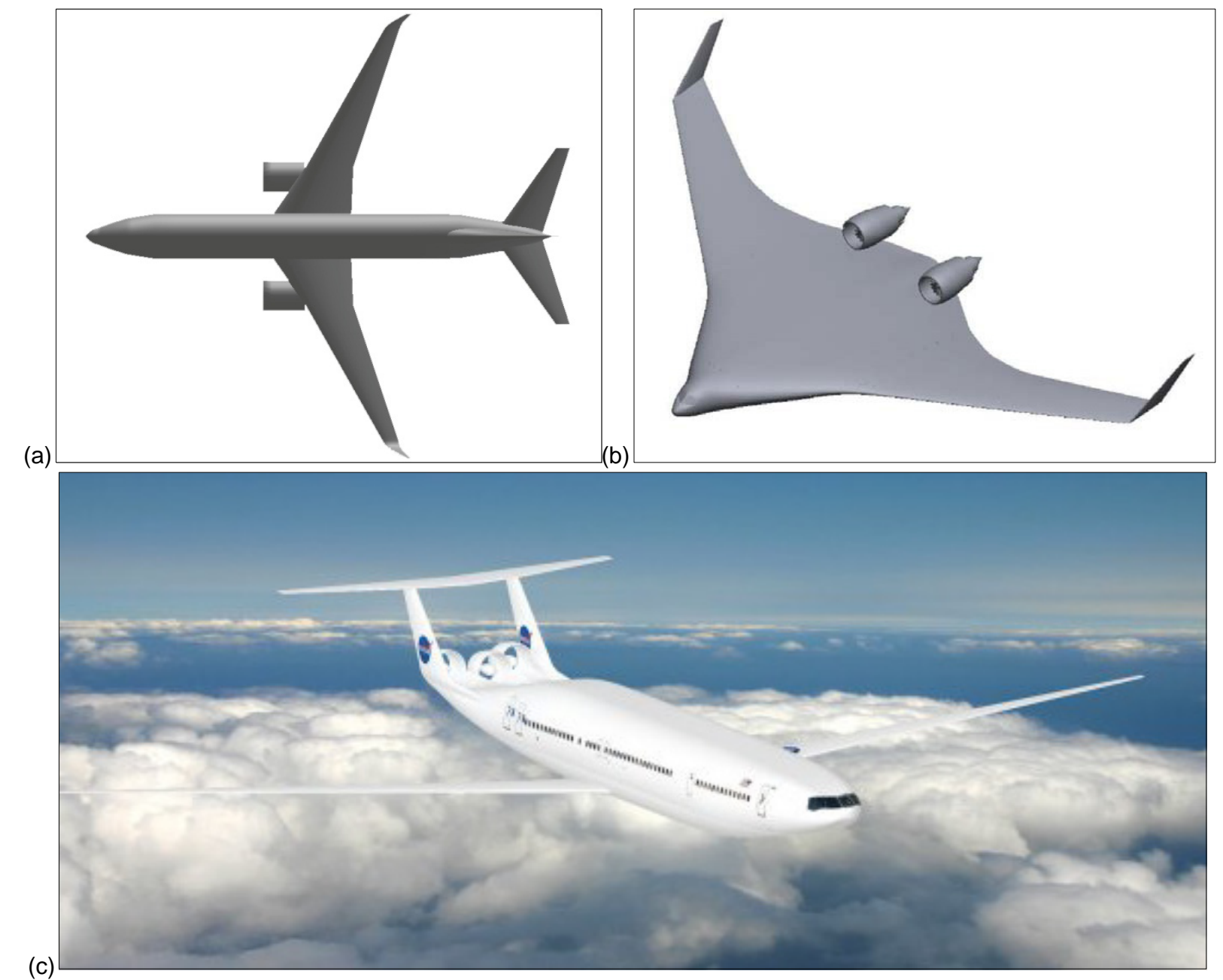

Figure 3.-Notional aircraft developed in $\mathrm{N}+1, \mathrm{~N}+2$, and $\mathrm{N}+3$ studies. Shown in panel (a) is the $\mathrm{N}+1$ study concept aircraft; a conventional single aisle aircraft that is predicted to come very close to meeting the $\mathrm{N}+1$ noise goal. In panel (b) is the N+2 study concept aircraft, which is predicted to meet the N+2 noise goal. Panel (c) depicts an N+3 concept aircrafts, called "double bubble", developed by a team headed by MIT. Like other concepts developed under N+3 NASA funded studies (see Refs. 6 to 10), it does not meet the N+3 noise goal.

Where applicable, the $\mathrm{N}+1, \mathrm{~N}+2$, and $\mathrm{N}+3$ studies benefited from ideas and technologies that are being developed by NASA to make the quiet aircraft of the future possible. These technologies encompass both airframe and engine noise reduction, but since engine noise is the major contributor to the overall noise produced by an aircraft under most operating conditions, the focus of this paper is on the NASA propulsion noise reduction research. This research is comprised of work conducted at NASA as well as sponsored work carried out in partnership with industry and academic partners under the sponsorship of the SFW and ERA projects.

\section{Engine Noise Reduction}

Fundamentally, there are three approaches for reducing aircraft propulsion noise: advantageous changes to the engine cycle, application of engine noise reduction technology, and judicious integration of the propulsion system with the airframe to prevent (i.e., shield) some or most of the engine noise from propagating to the community below. Currently, NASA has active research efforts in all three areas. The remainder of the paper is devoted to outlining these efforts. 


\section{Engine Cycle Benefits}

Changes to the engine cycle can have a significant influence on engine noise emissions. One of the most dramatic ways to reduce the noise output of an engine is to increase its bypass ratio. ${ }^{2}$ In fact, it has been known that increasing the engine bypass ratio, which is typically accompanied by reductions in the fan tip speed and bypass jet exhaust velocity, can noticeably reduce the strength of two principal sources of engine noise, namely, the fan and jet sources (Ref. 12). Figure 4 shows the theoretical reductions in the engine noise output as the bypass ratio is increased. ${ }^{3}$ Of course, nacelle drag considerations, weight penalty, and the availability of the liner treatment area place practical limits on how large the bypass ratio of a turbofan engine can actually be.

However, the full potential of the design trade space remains untapped, so there is still room for improvement. For example, the largest bypass ratio engines in service today (i.e., the General Electric GE-90 and Rolls-Royce Trent 1000) have bypass ratios in the range 9 to 10 . Judging from Figure 4, there is still significant noise reduction potential to be exploited by increasing the bypass ratios beyond 10. In fact, the notional engine considered in the NASA N+1 noise study described in Reference 3 has a bypass ratio of 16. The fan noise model for that engine was developed based on the wind tunnel data acquired in a series of NASA and Pratt \& Whitney (P\&W) tests of an ultra-high bypass cycle fan concept called the Advanced Ducted Propulsor (ADP) which has a bypass ratio of 13.3. The ratios beyond 12 are sometimes referred to as the ultra-high bypass (UHB). The ADP tests (Refs. 13 to 18) were conducted between 1993

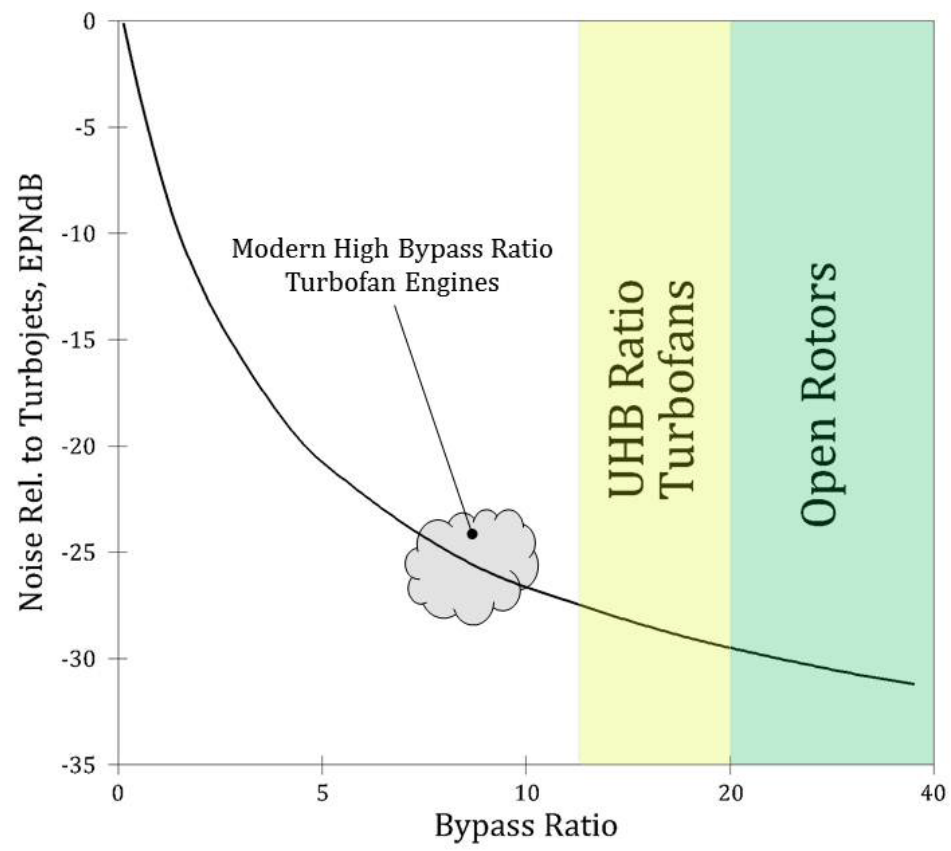

Figure 4.-Reduction of engine noise level as the bypass ratio increases. The reference (i.e., $0 \mathrm{EPNdB}$ ) is the noise level for a turbojet for which the bypass ratio is zero. The indicated ranges of bypass ratios for the ultra-high bypass ratio (UHBR) turbofans and open rotors shown here are notional. This graph is based on the information in Reference 12.

\footnotetext{
${ }^{2}$ Bypass ratio is the fan bypass mass flow rate divided by the core mass flow rate.

${ }^{3}$ The increase in the bypass ratio could potentially come at the expense of an increase in core noise (principally, compressor and turbine noise), but the overall noise reductions at present outweigh this potential penalty.
} 


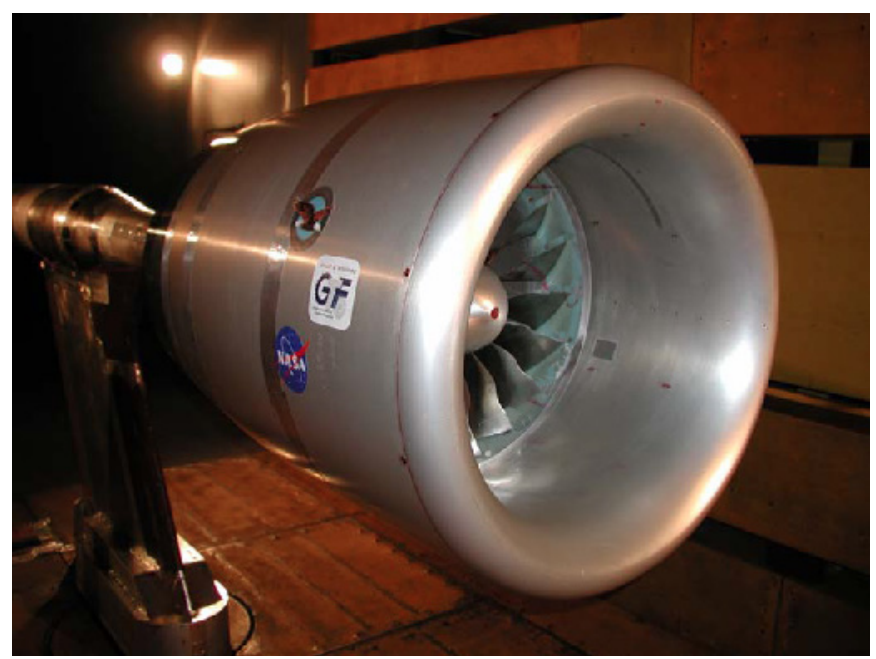

Figure 5.-NASA/P\&W 22-in. scale model Geared Turbofan (GTF) rig installed in the NASA 9- by 15-ft Low Speed Acoustic Wind Tunnel. Test results confirmed the acoustic benefits of ultra-high bypass ratio cycles.

and 1997 and laid the foundation for future work (Ref. 19). Based on the knowledge gained from these tests, NASA and P\&W demonstrated the significant acoustic benefits of a modern UHB fan design called the Geared Turbofan (GTF) in 22-in. model scale tests in the NASA 9- by 15-ft Low Speed Acoustic Wind Tunnel (see Fig. 5). P\&W subsequently carried out static tests of a full-scale GTF engine demonstrator convincingly proving its lower noise emissions compared with the current turbofans in its thrust class. Noise estimates based on the wind tunnel and static engine test data indicate that an aircraft with GTF engines can achieve a cumulative noise margin that is as much as 20 EPNdB below Stage 4 (Ref. 20).

Clearly, the GTF test results have shown the significant potential of the ultra-high bypass ratio turbofan technology in reducing aircraft engine noise. In follow up work to the original GTF research, NASA and P\&W are cooperatively working towards developing the second generation GTF fan design to further improve its aerodynamic performance margins while maintaining its noise margin (Ref. 21).

\section{Fan Noise Reduction Technology}

Despite its significant impact on engine noise, cycle change alone will not suffice in achieving the challenging noise reduction goals. Case in point is the NASA N+1 noise study in which cycle change is estimated to provide roughly two-thirds of the overall noise margin benefits. To reduce engine noise further, a suite of component noise reduction technologies must also be integrated into the design of the engine. These technologies target either the source of the noise itself by reducing its strength, or mitigate its radiation inside the engine nacelle by absorbing the noise. Under the SFW and ERA projects, a number of turbofan noise reduction technologies are being pursued that complement the acoustic benefits of the ultra-high bypass cycle. Some of these technologies are depicted in the sketch in Figure 6. These include Over-The-Rotor treatment, which is aimed at reducing the noise from the fan rotor; Soft Vane, which is designed to target rotor-stator interaction noise; and Active Liners, which reduce both inlet and exhaust radiated noise before it reaches the engine duct terminations.

These technologies, which are currently at various stages of development and maturity, will be described briefly in the next few paragraphs.

Over-The-Rotor (OTR) fan casing treatment is designed to reduce the noise associated with the fan rotor. The photo collage in Figure 7 depicts the OTR treatment and how it is packaged and integrated into a fan stage. The foam metal, used in the construction of the OTR treatment, is a porous metal (e.g., cobalt), or an alloy (e.g., iron-chromium-aluminum), that dissipates the acoustic energy of the sound 
waves that penetrate into it. Its density, porosity, and depth can be tailored to specific applications. The foam metal is formed into a fan casing ring or spool piece. The interior face of the fan casing ring is then covered by a porous sheet made of RenShape board as shown in the bottom right inset picture. The RenShape board allows the sound waves to pass through to the foam metal underneath while at the same time it provides a smooth flow surface as part of the nacelle interior. The panel on the bottom left shows the completed OTR fan casing spool piece integrated into the fan nacelle. It is worth mentioning that, ultimately, OTR could have dual use both as an acoustic treatment and as part of the fan containment structure.

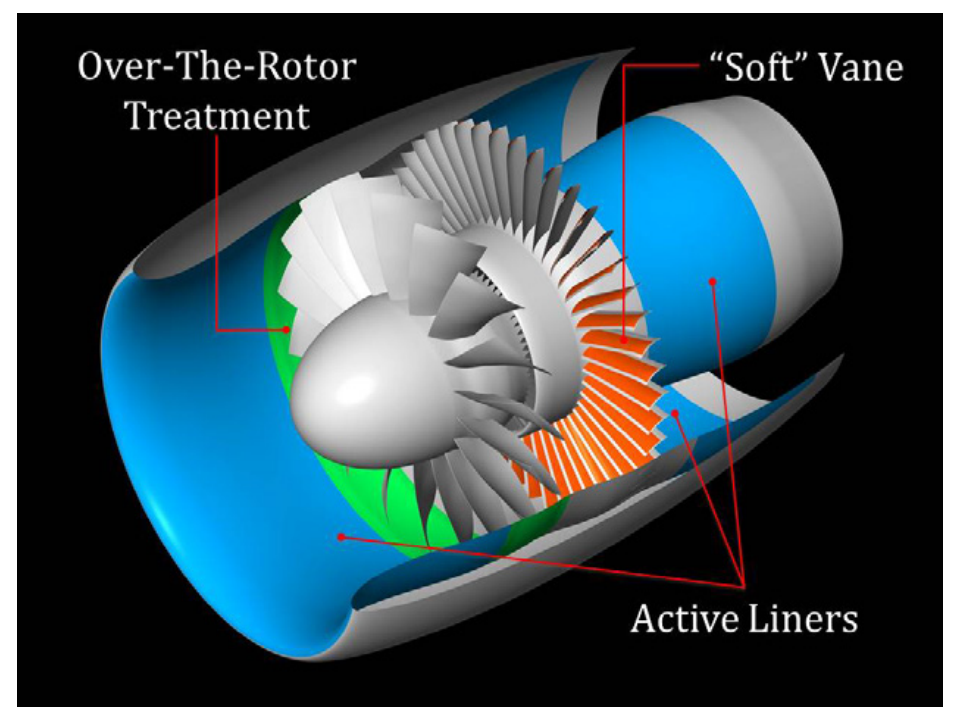

Figure 6.-Three promising fan noise reduction technologies; Over-The-Rotor treatment, Soft Vane, and Active Liners are shown installed in an UHB fan nacelle.

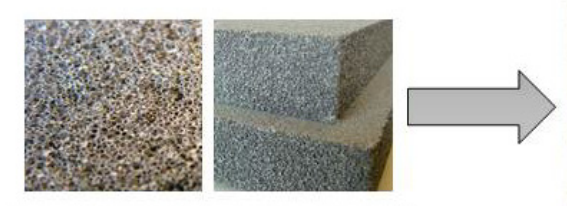

Dissipative Foam Metal

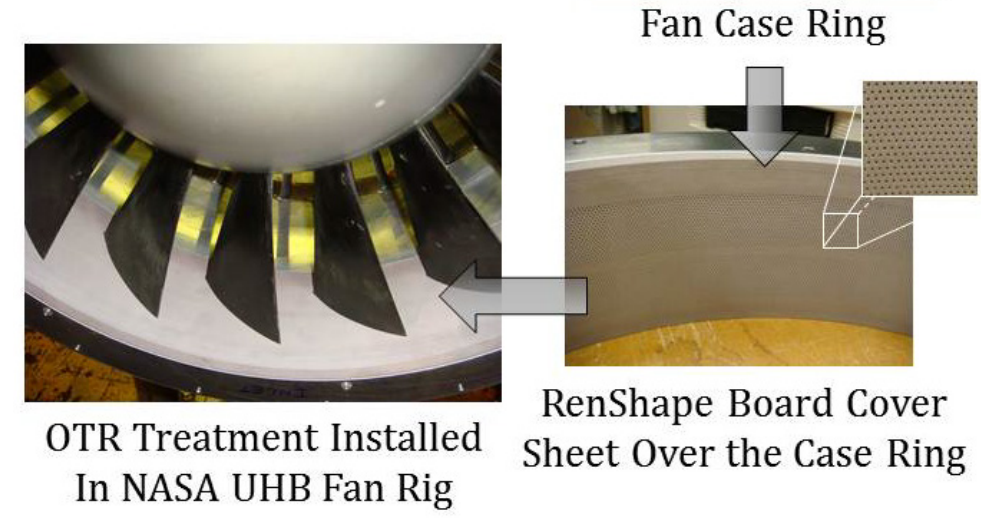

Figure 7.-Over-The-Rotor fan noise reduction concept and its packaging. The foam metal is formed into the fan casing ring, is covered with the RenShape board porous sheet, and is integrated into the fan case. This figure shows the first generation implementation of the concept. 
A first generation OTR designed for a realistic fan was tested in the NASA 9- by 15-ft Low Speed Acoustic Wind Tunnel using NASA's 22-in. ADP ultra-high bypass fan rig. Figure 8 shows a typical result (Refs. 22 and 23) where the change relative to the hardwall configuration in the measured broadband sound pressure level $(\Delta \mathrm{SPL})$ is plotted as function of the model scale frequency and sideline angle. Negative levels (blue) represent reduction in SPL. The results clearly show that this implementation of OTR increased noise at frequencies between 1 and $5 \mathrm{kHz}$. The cause was traced to an unanticipated aerodynamic behavior of this implementation of OTR concept. The cyclic pressure fluctuation at the boundary of the treatment due to the passage of the rotor blades created local high speed jets of air in and out of the treatment generating measurable extraneous noise and in the process probably masking any potential noise reduction benefits of the technology.

To correct this problem, a second generation design is being developed to eliminate the possibility of this aerodynamically driven "pumping" action at the surface of the treatment. Rather than a porous material, in the new design a dense arrangement of individual small-diameter holes (i.e., channels) are drilled into a solid fan case ring. These channels serve as Helmholtz resonators and act to dissipate the incident acoustic energy. The channels are independent and do not communicate with each other. This feature, combined with the small diameter of the channels, should prevent any aerodynamic motion at the surface. As before there will be a porous cover sheet over the case ring.

"Soft" vane (SV) is a noise mitigation concept designed to reduce the noise associated with the interaction of the fan rotor wakes with the outlet guide vanes in a turbofan engine. This is the so-called rotor-stator interaction noise, which is a major contributor to engine noise for a modern turbofan especially an ultra-high bypass one. The collage in Figure 9 shows the SV concept and how it is packaged and integrated into a fan stage. SV is a hollow vane (see top left panel) that has several internal chambers, or Helmholtz resonators, each of which is sized to mitigate a particular frequency of the vane surface unsteady pressure spectrum. In this particular realization of the SV concept, the chambers run the span of the vane and extend chordwise from 5 percent of the leading edge to 40 percent. The chambers can communicate with the external environment on the suction side of the vane through a perforated surface

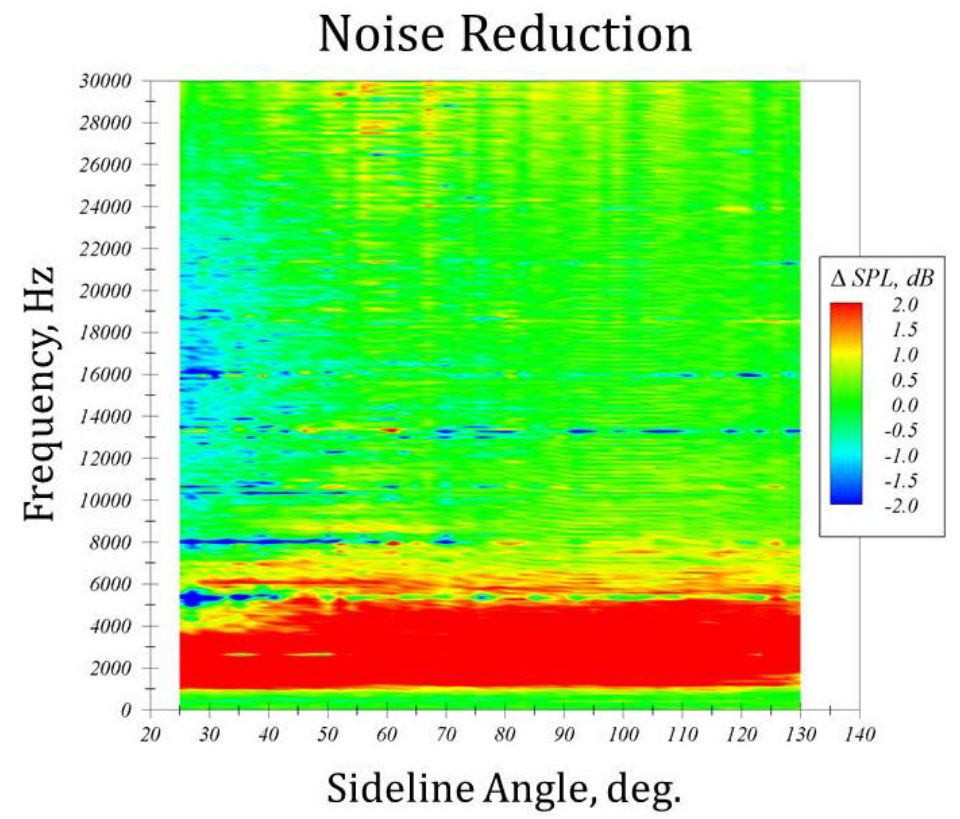

Figure 8.-Shown is typical result for the first generation implementation of the Over-The-Rotor treatment. Negative $\triangle$ SPL (blue) indicates a reduction in noise. Over a wide range of sideline angles and in the frequency range of 1 to $5 \mathrm{kHz}$, this implementation of the OTR concept actually created noise instead of abating it. 
as shown in the upper left panel of Figure 9. The exposed surface is then covered by a felt metal sheet, which allows the sound waves to pass through into the internal cavities, but not the air flow. The completed stator vane assembly is shown installed in fan rig in the bottom left panel.

A first generation SV design designed for a realistic fan was tested in the NASA 9- by 15-ft Low Speed Acoustic Wind Tunnel using NASA's 22-in. ADP ultra-high bypass fan rig. A typical test result (Refs. 22 and 23) is shown in Figure 10 which shows that, over a wide range of frequencies, the radiated broadband noise to the sideline was reduced by an average of $1 \mathrm{~dB}$ (as before blue represent reduction). This is half of the target reduction, but it nonetheless proved the feasibility of the Soft Vane concept for realistic fan stages. It should be noted that the impact of this implementation of Soft Vane on the aerodynamic performance of the fan stage was small and caused less than 0.5 percent of thrust loss.

To achieve the full potential of the Soft Vane technology, a second generation design is being developed with the aim of improving the acoustic performance while reducing the aerodynamic penalty. The new idea for the second generation Soft Vane is the use of small-diameter channels that need not be straight. This provides greater flexibility for the location of the channels within the vane as well as increases the number of channels that can be incorporated into the design thus providing for greater frequency range of effectiveness.

Use of liners has traditionally been the principal way that the noise generated inside an aircraft engine is mitigated. Liners are integrated into all commercial engines in service today and will certainly be integrated into future engines as well. Therefore, there continues to be a critical need for the development of more effective liners. Nearly all conventional liners in use today are passive and are designed to target a specific frequency, or frequency range, and are typically more effective the larger the treatment area available. However, with the emergence of UHB engines, for which reducing the nacelle length and thickness is paramount if the nacelle drag and weight are to be controlled, the shrinking liner treatment area makes the use of conventional liners somewhat problematic. Complicating matters further is that a shorter nacelle means the inflow into the engine is likely to be more distorted during takeoff and landing operations resulting in more transient acoustic behavior, which makes designing an optimum passive liner

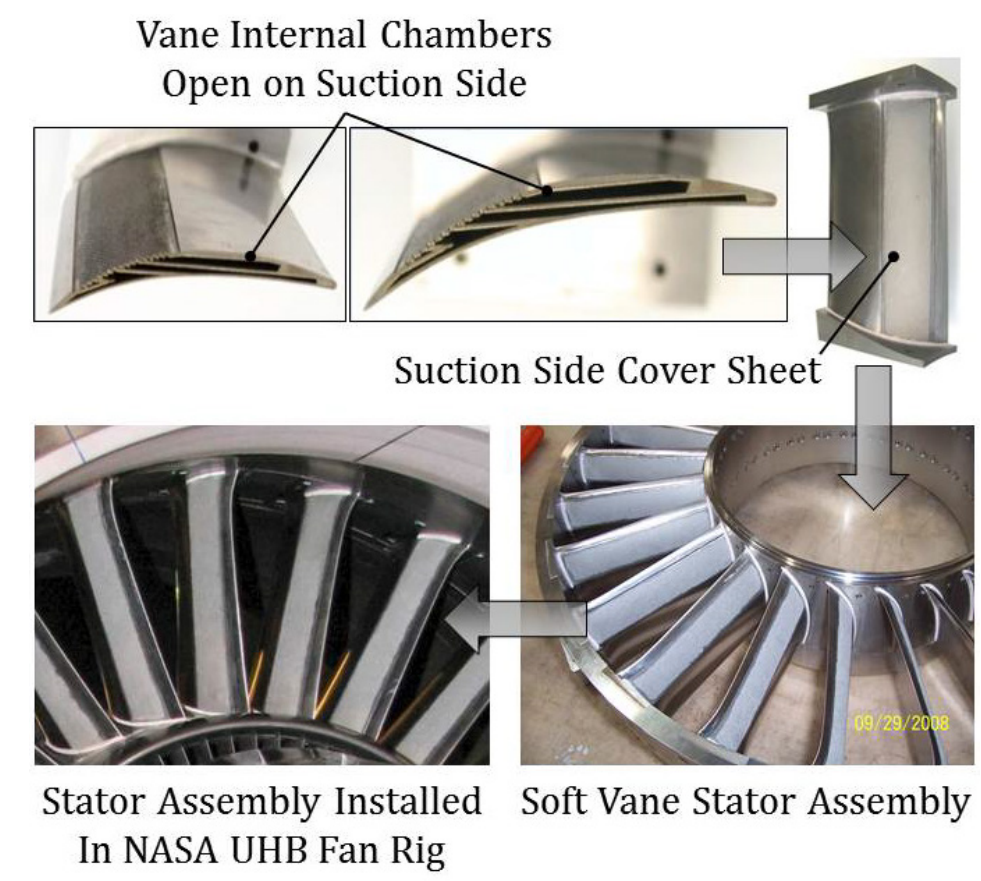

Figure 9.-Soft Vane fan noise reduction concept and its packaging. The hollow vanes internal chambers are tuned to a range of target frequencies and are open on the suction side of the vane. A felt metal mesh cover sheet provides a smooth flow surface. 


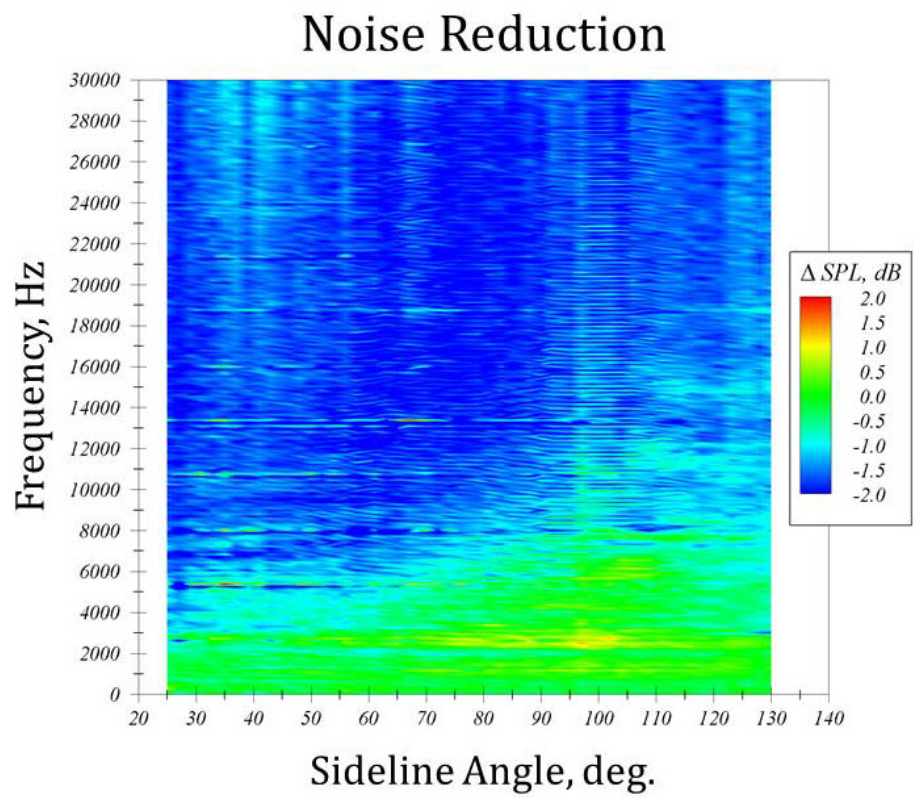

Figure 10.-Typical result for the first generation implementation of the Soft Vane. Over a wide range of sideline angles and frequencies, SV reduced the radiated sideline noise. The average reduction over the entire range of angles and frequencies is around $1 \mathrm{~dB}$.

a difficult task. ${ }^{4}$ A potential solution is to use active, and adaptive, liners that can adjust to the temporal and spatial variations of the incident acoustic field and tailor their response optimally. There is a growing interest in this area and a number of concepts have been proposed. One, in particular, is an electromechanical self-powered liner (Refs. 24 to 29). The sketches in Figure 11 show a comparison of the basic designs of a conventional passive liner and the proposed active electromechanical liner. On the left, typical single and double layer conventional passive liners are depicted. These liners are constructed of a honeycomb backing-layer for a single layer type, and two honeycomb backing-layers for double layer type. In each case, the top of the honeycomb layer is covered with a porous faceplate, which is exposed to the airflow. Conventional liners, being passive, are designed to mitigate sound in pre-selected frequencies, typically, a primary frequency and its first odd harmonic. The double layer liner provides some additional mitigation in the frequency range between the target frequencies as compared with the single layer liner. In contrast, the electromechanical liner shown on the right is active in the sense that it is self-adjusting to the frequencies it targets owing to the use of sensor and actuator circuitries. As shown in the sketch in Figure 11, the electromechanical liner includes, in some of its cells, an actuated resonator. The bottom of each resonator cell has a compliant surface that is actively controlled to produce the desired impedance, thus making the resonator appear deeper or shallower as needed. The result is a resonator that is always frequency-tuned optimally for cancelling the incident sound. The actuators are controlled by micro-electro-mechanical systems (MEMS) that monitor the incident sound environment through embedded sensors in the liner and adjust the response frequency of the actuators in order to precisely target the incident sound field in terms of its amplitude and frequency content. Additionally, the electromechanical liner is self-powered in that some of its cells are equipped with energy harvesting elements constructed, for example, from piezo-electric material that convert a portion of the energy of the incident sound field into electrical energy that drives the sensors, actuators, and the MEMS control system. Individual components of this advanced liner have been successfully tested in the laboratory, but the testing of the assembled liner system remains to be carried out (see Refs. 24 to 29 for more details).

${ }^{4}$ Passive bulk absorbers, which have a relatively large frequency range of suppression, are prone to absorbing water and oil and losing their effectiveness over time. 


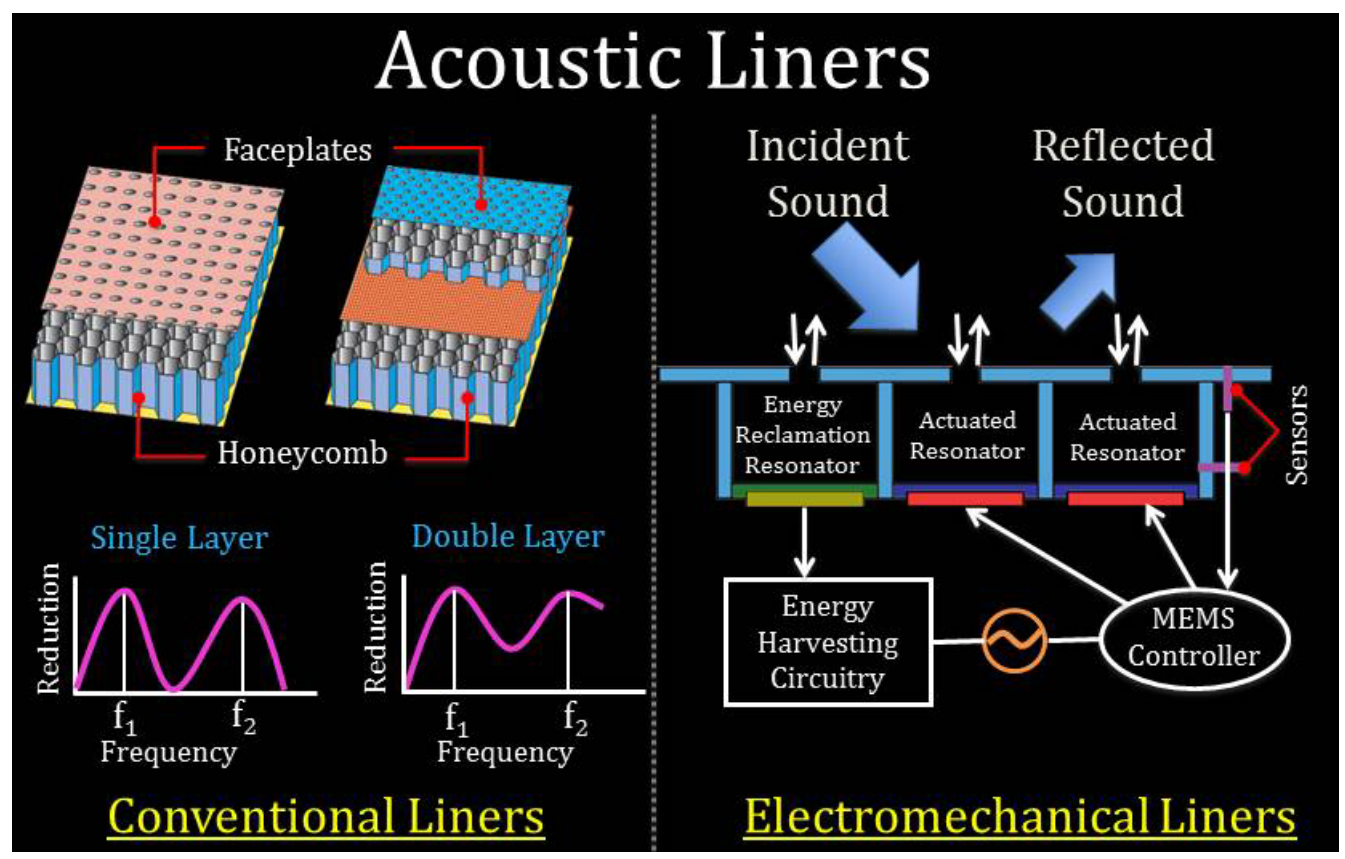

Figure 11.-Shown are the schematic description of a conventional liner on the left and an advanced self-powered, self-tuning electromechanical liner on the right.

\section{Noise Shielding}

In addition to cycle change and application of engine noise reduction technology, careful integration of the propulsion system with the airframe could also be a powerful tool for reducing engine noise. In fact, significant potential exists for blocking some of the engine noise directed towards the ground by judicious installation of the engines. As indicated in the four artist concepts shown in Figure 12, the integration could be accomplished by placing the engines above the wing or fuselage. This is true whether one is considering a turbofan or an open rotor engine, or whether the airframe is conventional or advanced. The top left concept is that of a hybrid wing body airframe with two turbofan engine pods installed above the body. The top right concept is that of a conventional tube and wing airframe with two aft mounted open rotor pusher engines that are partially shielded by the horizontal and vertical tail surfaces that enclose the two engines on the bottom and the sides. The bottom right concept depicts a hybrid wing body airframe with two open rotor engines installed on top of the body. The fourth concept is that of a tube and wing airframe with the turbofan engine pods installed on top of the wing. All of these concepts provide for at least partial shielding of the engine noise via the airframe or wing.

In order to quantify the benefits of engine noise shielding by the airframe (i.e., fuselage and/or wing), NASA has been working in cooperation with Boeing to examine the nuances of propulsion airframe integration as well conducting basic shielding experiments. As part of these efforts, detailed propulsion airframe integration tests have been conducted in Boeing's Low Speed Aeroacoustics Facility (LSAF) using turbofan and open rotor noise simulators with a conventional tube and wing airframe model as well as an advanced airframe model called the blended wing body (BWB). The basic shielding experiments were carried out in the NASA 9- by 15-ft Low Speed Acoustic Wind Tunnel using a scale model open rotor $^{5}$ and a barrier wall representing a simplified wing or empennage (Ref. 30). The results from these tests have provided significant insight into the benefits of shielding as a viable means of reducing engine noise.

\footnotetext{
${ }^{5}$ Depending on the application of interest (i.e., regional jet versus single aisle), the scale factor for the NASA open rotor model, which is nominally 27 in. in diameter, is in the range $1 / 5^{\text {th }}$ to $1 / 7^{\text {th }}$.
} 

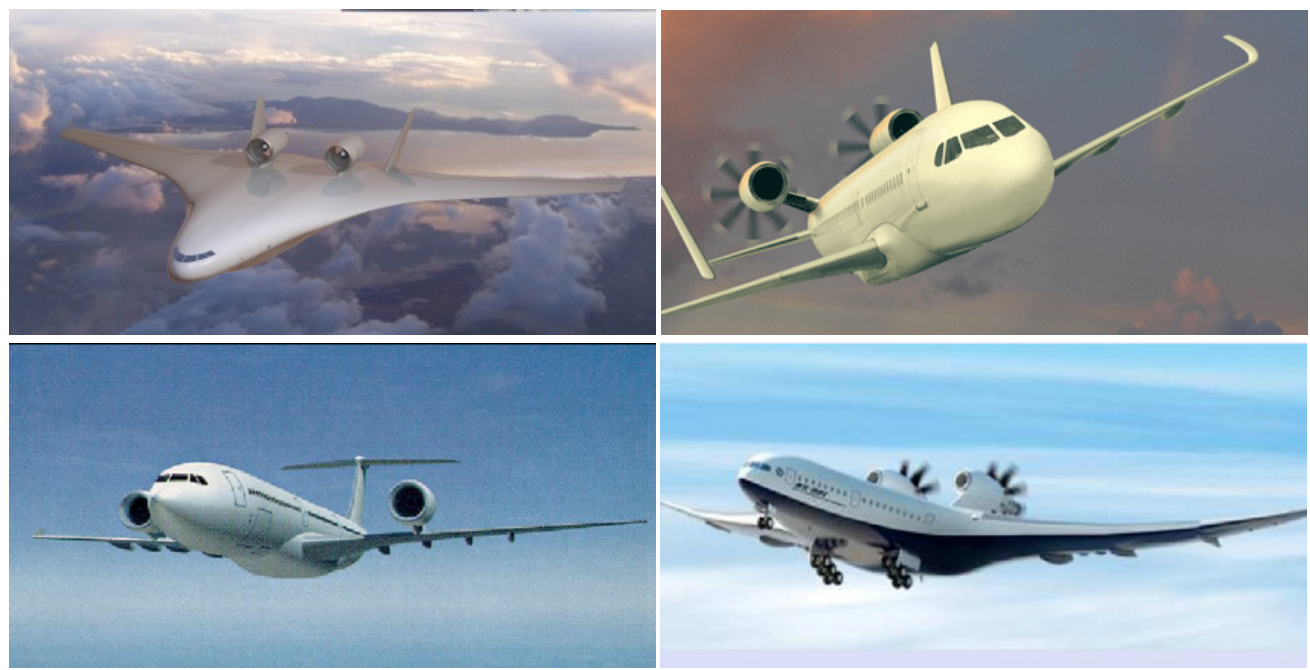

Figure 12.-Four novel engine/airframe integration concepts with the potential for significant shielding of engine noise by the airframe.
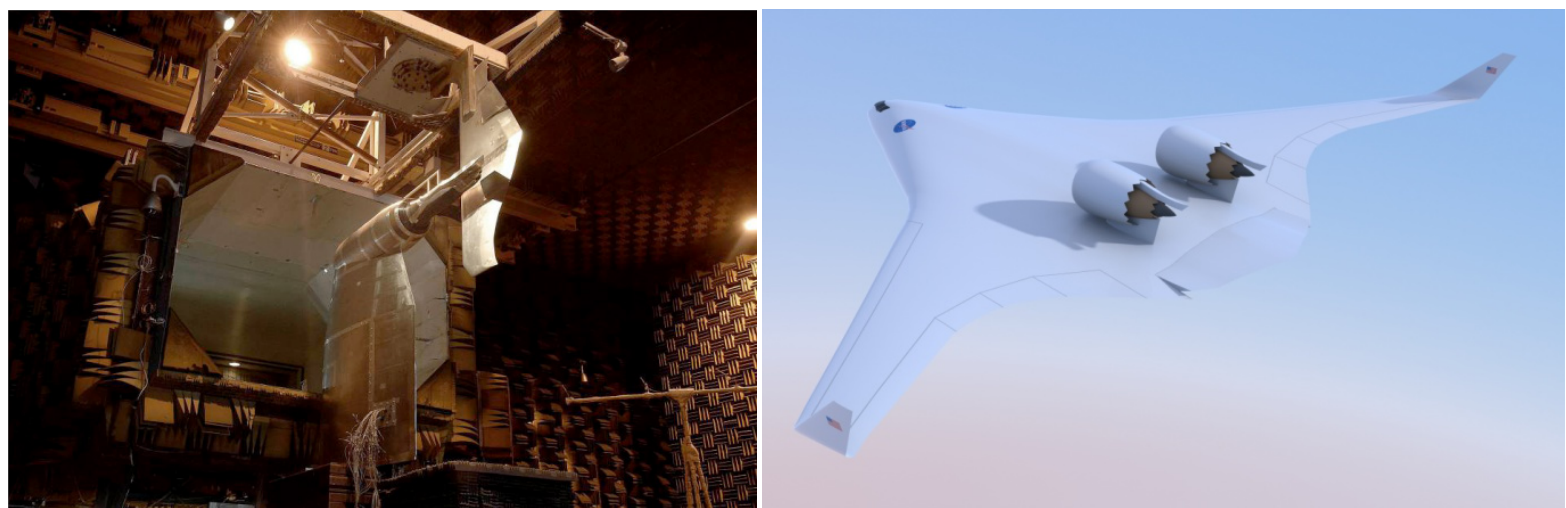

Figure 13.-NASA/Boeing propulsion aeroacoustics tests were conducted in Boeing's Low Speed Aeroacoustic Facility shown on the left. In the middle of the picture is the simulated nozzle just to the left of the Blended Wing Body planform suspended vertically from the ceiling. On the right, is an artist's rendering of the quietest configuration studied in References 4 and 5. Note the location of the nozzles (fan and core) both of which are located well upstream of the BWB trailing edge to shield the noise from reaching the observer below. The design of the chevrons and pylons (in keel and crown positions) were optimized for noise reduction.

The LSAF test results for the shielding of turbofan jet noise are summarized in References 4 and 5 . A photograph of the facility with the test article is shown in the left panel of Figure 13. The results for the integration of an open rotor noise simulator with the airframe are discussed in Ref. 31. The basic conclusion from the study in References 4 and 5 is that as much as 20 EPNdB cumulative reduction in jet noise is possible by proper shielding of jet noise. An important element of this study was the use of aggressive chevrons which mitigate the low frequency (i.e., large scale) jet noise and, at the same, also bring the location of the peak high frequency (i.e., fine scale) jet noise closer to the nozzle exit plane thereby making this source component better shielded. In short, the location of the engines and the use of chevrons serve to enhance the effectiveness of shielding by the airframe (see the right panel of Fig. 13). The conclusions of this study will be refined when a planned test campaign in NASA 14- by 22-ft Subsonic Wind Tunnel is conducted in 2012. 

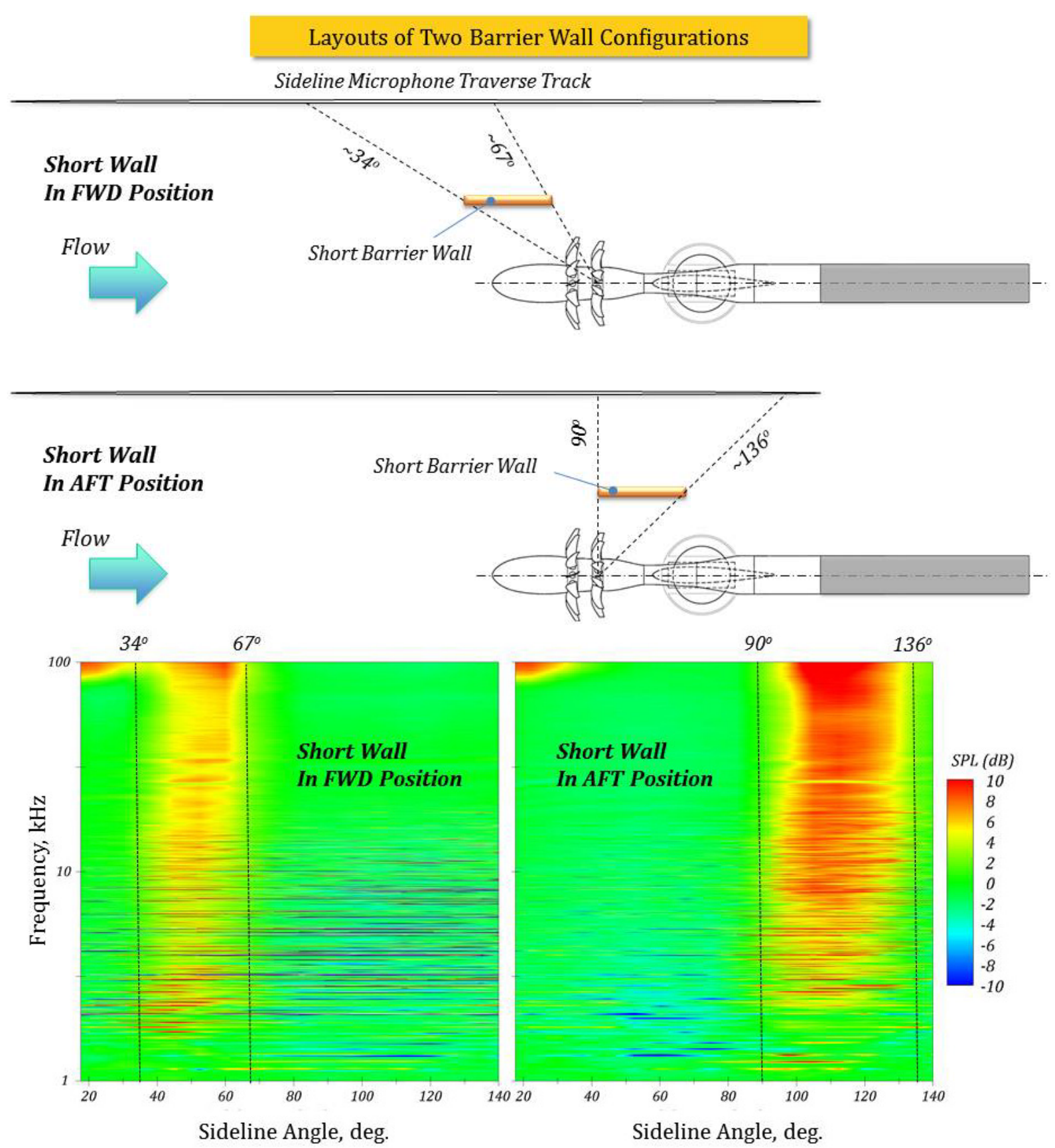

Figure 14.-Basic shielding experiment layout and sample results. The sketches on top show the position of the open rotor model and barrier wall in forward and aft positions (plan view is shown). The contour plots on the bottom show change in sideline sound pressure level (free field - shielded) as a function of frequency and over a range of sideline angles. Positive numbers (red) are reduction in SPL (i.e., shielding benefits). Note that for angles that are in the shadow region of the barrier there is significant noise shielding, especially for the barrier in the aft position.

The layout of the basic shielding experiment carried out in the NASA 9- by 15-ft wind tunnel along with some representative results are shown in Figure 14. Of the four shielding configurations investigated in this study, the two short barrier positions shown are most representative of shielding by a wing or an empennage. The contour plots in this figure show the change in the sound pressure level, i.e., free field minus shielded, over the range of scaled frequencies from 1 to $100 \mathrm{kHz}$, and over a wide range of sideline angles. Here positive numbers (red levels) represent noise reduction. The results indicate that there is 


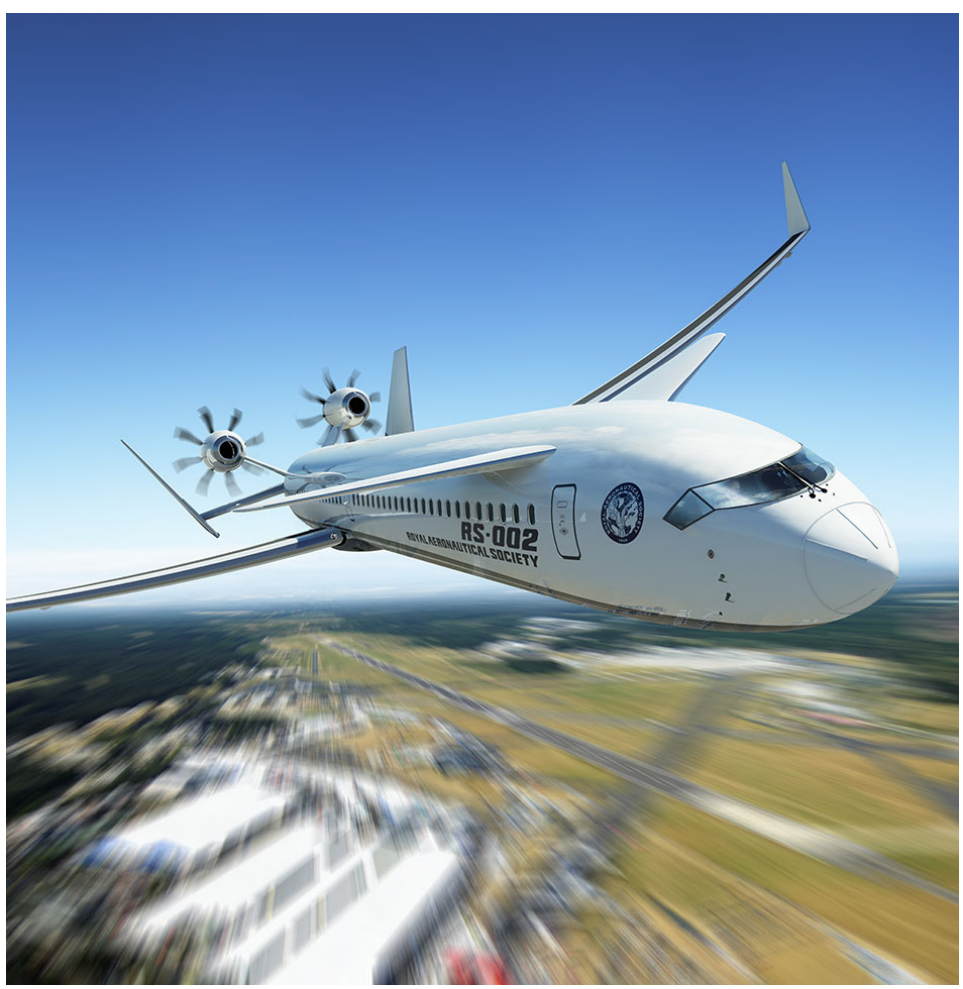

Figure 15.- The type of empennage shielded open rotor engine installation analyzed in the study described in Reference 32. The Utail is providing significant shielding below and to the side of the engines.

significant shielding benefit in the shadow region of the barrier especially for the barrier in the aft position. Using data from this test, a system study (described in Ref. 32) was carried out to estimate system level noise reduction benefits of shielding by an empennage for a tube and wing type transport with open rotor engines. The analysis suggests that a U-tail empennage such as that shown in Figure 15 could provide as much as $8 \mathrm{EPNdB}$ cumulative noise reductions when it is judiciously placed relative to the open rotor engines. Owing to the inherent limitations of this test data, this reduction may not represent a true system level assessment of actual flight data. Nonetheless, the experimental evidence used in this study as well as those from the LSAF test campaigns strongly suggest that shielding of the engine noise by the airframe and/or wing may be an effective noise reduction tool in the drive to design low-noise aircraft that could meet the aggressive national noise goals.

\section{Conclusions}

NASA is actively exploring a number of noise mitigation strategies for reducing propulsion noise for future aircraft that could meet the aggressive national subsonic transport noise emission reduction goals. Some of these concepts have been tested, or are being tested while others are in conceptual development stages. The goal is to provide a portfolio of low-noise strategies for aircraft designers that do not compromise the other performance aspects of the aircraft. 


\section{References}

1. “FAA Aerospace Forecast - Fiscal years 2010 - 2031,” Federal Aviation Administration, Aviation Policy and Plans, URL:

http://www.faa.gov/about/office_org/headquarters_offices/apl/aviation_forecasts/aerospace_forecast s/2011-2031/media/ 2011\%20Forecast\%20Doc.pdf.

2. "National Aeronautics Research and Development Plan, Biennial Update, February 2010," The National Science and Technology Council, URL:

http://www.whitehouse.gov/sites/default/files/microsites/ostp/aero-rdplan-2010.pdf.

3. Berton, J. J., Envia, E., and Burley, C. L., "An Analytical Assessment of NASA N+1 Subsonic Fixed Wing Project Noise Goal,” $15^{\text {th }}$ AIAA/CEAS Aeroacoustics Conference, paper no. 2009-3144, May 2009.

4. Thomas, R. H., Burley, C. L., Olson, E. D., "Hybrid Wing Body Aircraft System Noise Assessment With Propulsion Airframe Aeroacoustics Experiments," $16^{\text {th }}$ AIAA/CEAS Aeroacoustics Conference, paper no. 2010-3913, June 2010.

5. Czech, M. J., Thomas, R. H., and Elkoby, R., "Propulsion Airframe Aeroacoustic Integration Effects for a Hybrid Wing Body Aircraft Configuration," $16^{\text {th }}$ AIAA/CEAS Aeroacoustics Conference, paper no. 2010-3912, June 2010.

6. D’Angelo, M. M., et al., “N+3 Small Commercial Efficient and Quiet Transportation for Year 20302035,” NASA/CR—2010-216691, May 2010.

7. Bruner, S., et al., "NASA N+3 Subsonic Fixed Wing Silent Efficient Low-Emissions Commercial Transport (SELECT) Vehicle Study,” NASA/CR—2010-216798, November 2010.

8. Greitzer, E. M., et al., "N+3 Aircraft Concept Designs and Trade Studies, Final Report,” Volumes 1 \& 2, NASA/CR—2010-216794, December 2010.

9. Bradley, M., Droney, C. K., and Paisley, D., "Boeing N+3 Subsonic Ultra Green Aircraft Research, Propulsion Technologies” Presentation at the Fundamental Aeronautics Technical Conference, March 15-17, 2011, Cleveland, Ohio.

10. Bradley, M., and Droney, C. K., "Boeing N+3 Subsonic Ultra Green Aircraft Research, Concepts and Technologies” Presentation at the Fundamental Aeronautics Technical Conference, March 1517, 2011, Cleveland, Ohio.

11. Crichton, D., de la Rosa Blanco, E., Law, T. R., and Hileman, J. I., "Design and operation for ultra low noise take-off," 45 ${ }^{\text {th }}$ AIAA Aerospace Sciences Meeting and Exhibit, paper no. 2007-456, January 2007.

12. Smith, M. J. T., Aircraft Noise, Cambridge Aerospace Series, Cambridge University Press, New York, 1989, Chap. 8.

13. Woodward, R. P., Bock, L. A., Heidelberg, L. J., and Hall, D. G., "Far-Field Noise and Internal Modes From a Ducted Propeller at Simulated Aircraft Takeoff Conditions,” $30^{\text {th }}$ Aerospace Sciences Meeting and Exhibit, paper no. 92-0371, January 1992.

14. Dittmar, J. H., Hughes, C. E., Bock, L. A., and Hall, D. G., "Cruise Noise Measurements of a Scale Model Advanced Ducted Propulsor,” $15^{\text {th }}$ AIAA Aeroacoustics Conference, paper no. 93-440, October 1993.

15. Low, J. K. C., “Ultra-High Bypass Ratio Jet Noise,” NASA/CR—195394, October 1994.

16. Hobbs, D. E., Neubert, R. J., Malmberg, E. W., Philbrick, D. H., and Spear, D. A., "Low Noise Research Fan Stage,” NASA/CR—195382, March 1995.

17. Neubert, R. J., Bock, L. A., Malmborg, E. W., and Owen-Peer, W., “Advanced Low-Noise Research Fan,” NASA/CR-97-206308, December 1997.

18. Dittmar, J. H., Elliott, D. M., and Bock, L. A., "Some Acoustic Results from Pratt and Whitney Advanced Ducted Propulsor,” NASA/TM-1999-209049, March 1999.

19. Holcombe, V., “Aero-Propulsion Technology (APT): Task V—Low Nose ADP Engine Definition Study”, NASA/CR-2003-212521, October 2003. 
20. Epstein, A., "Reducing Environmental Impact With New Technology: The PW Geared Turbofan Engine,” ACI Environmental Affairs Conference, Denver, May 2008.

21. Hughes, C. E., “Aircraft Engine Technology for Reducing Fuel Burn in Green Aviation,” $3^{\text {rd }}$ AIAA Atmospheric and Space Environment Conference, to be published, June 2011.

22. Elliott, D. M., Woodward, R. P., Podboy, G. G., "Acoustic Performance of Novel Fan Noise Reduction Technologies for a High Bypass Model Turbofan at Simulated Flight Conditions," $15^{\text {th }}$ AIAA/CEAS Aeroacoustics Conference, paper no. 2009-3140, May 2009.

23. Envia, E., "Review of the Over-The-Rotor and Soft Vane Wind Tunnel Acoustic Test Results," NASA Acoustics technical Working Group Meeting, Hampton, VA, October 28-20, 2009.

24. Horowitz, S., Nishida, T., Cattafesta III, L. N., Sheplak, M., "Compliant-Backplate Helmholtz Resonators for Active Noise Control Applications,” $39^{\text {th }}$ Aerospace Sciences Meeting and Exhibit, paper no. 2001-0817, January 2001.

25. Prasad, S. A. N., Sankar, B. V., Cattafesta III, L. N., Horowitz, S., Gallas, Q., Sheplak, M., “TwoPort Electroacoustic Model of an Axisymmetric Piezoelectric Composite Plate," $43^{\text {rd }}$

AIAA/ASME/ASCE/AHS/ASC Structures, Structural Dynamics, and Materials Conference, paper no. 2002-1365, 2002.

26. Horowitz, S. B., Nishida, T., Cattafesta III, L. N., Sheplak, M., "Characterization of CompliantBackplate Helmholtz Resonators for an Electromechanical Acoustic Liner," International Journal of Aeroacoustics, 1(2), pp.183-205, 2002.

27. Liu, F., Horowitz, S., Nishida, T., Cattafesta III, L. N., Sheplak, M., “A Tunable Electromechanical Helmholtz Resonator," 9 ${ }^{\text {th }}$ AIAA/CEAS Aeroacoustics Conference, paper no. 2003-3145, May 2003.

28. Jones, K. H., Nark, D. M., Jones, M. G., Lodding, K., N., "Emergent Adaptive Noise Reduction from Communal Cooperation of Sensor Grid,” $13^{\text {th }}$ International Conference on Information Fusion, July 2010.

29. Jones, K. H., Nark, D. M., Jones, M. G., “Communal Sensor Network for Adaptive Noise Reduction in Aircraft Engine Nacelles,” IEEE Sensors 2011, 2011.

30. Stephens, D. B., and Envia, E., “Acoustic Shielding for Model Scale Counter-Rotation Open Rotor,” $17^{\text {th }}$ AIAA/CEAS Aeroacoustics Conference, paper no. 2011-2940, June 2011.

31. Czech, M. J., and Thomas, R. H., "Experimental Studies of Open Rotor Installation Effects,” Oral presentation at $3^{\text {rd }}$ AIAA Atmospheric and Space Environment Conference, June 2011.

32. Berton, J. J., "Empennage Noise Shielding Benefits for an Open Rotor Transport," $17^{\text {th }}$ AIAA/CEAS Aeroacoustics Conference, paper no. 2011-2764, June 2011. 



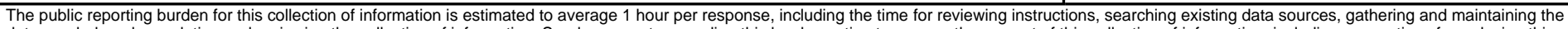

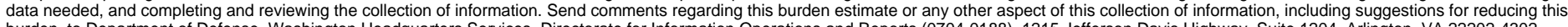

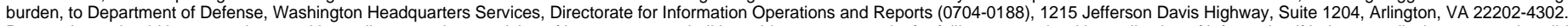

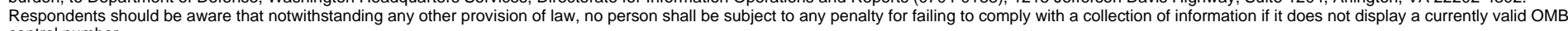

control number.
PLEASE DO NOT RETURN YOUR FORM TO THE ABOVE ADDRESS.

\begin{tabular}{l|l|l} 
1. REPORT DATE (DD-MM-YYYY) & $\begin{array}{l}\text { 2. REPORT TYPE } \\
\text { Technical Memorandum }\end{array}$ & 3. DATES COVERED (FrOm - To) \\
\end{tabular}

\section{TITLE AND SUBTITLE}

5a. CONTRACT NUMBER

Emerging Community Noise Reduction Approaches

5b. GRANT NUMBER

5c. PROGRAM ELEMENT NUMBER

6. AUTHOR(S)

Envia, Edmane 5d. PROJECT NUMBER

5e. TASK NUMBER

5f. WORK UNIT NUMBER

WBS 699959.02.09.03.06

7. PERFORMING ORGANIZATION NAME(S) AND ADDRESS(ES)

National Aeronautics and Space Administration

John H. Glenn Research Center at Lewis Field

Cleveland, Ohio 44135-3191

9. SPONSORING/MONITORING AGENCY NAME(S) AND ADDRESS(ES)

National Aeronautics and Space Administration

Washington, DC 20546-0001
8. PERFORMING ORGANIZATION

REPORT NUMBER

E-18003

10. SPONSORING/MONITOR'S ACRONYM(S)

NASA

11. SPONSORING/MONITORING REPORT NUMBER

NASA/TM-2012-217248

\section{DISTRIBUTION/AVAILABILITY STATEMENT}

Unclassified-Unlimited

Subject Category: 71

Available electronically at http://www.sti.nasa.gov

This publication is available from the NASA Center for AeroSpace Information, 443-757-5802

\section{SUPPLEMENTARY NOTES}

\section{ABSTRACT}

An overview of the current NASA research portfolio in the area of aircraft noise reduction is presented. The emphasis of the research described herein is on meeting the aggressive near- and mid-term national goals for reducing aircraft noise emissions, which NASA internal studies have shown to be feasible using noise reduction technologies currently being developed in-house or in partnership with NASA's industry and academic partners. While NASA has an active research effort in airframe noise reduction, this overview focuses on propulsion noise reduction only.

\section{SUBJECT TERMS}

Aerodynamic noise; Engine noise; Noise reduction

\begin{tabular}{|c|c|c|c|c|}
\hline \multicolumn{3}{|c|}{ 16. SECURITY CLASSIFICATION OF: } & \multirow{2}{*}{$\begin{array}{l}\text { 17. LIMITATION OF } \\
\text { ABSTRACT } \\
\text { UU }\end{array}$} & \multirow{2}{*}{$\begin{array}{l}\text { 18. NUMBER } \\
\text { OF } \\
\text { PAGES } \\
24\end{array}$} \\
\hline $\begin{array}{l}\text { a. REPORT } \\
\text { U }\end{array}$ & $\begin{array}{l}\text { b. ABSTRACT } \\
U\end{array}$ & $\begin{array}{l}\text { c. THIS } \\
\text { PAGE } \\
\text { U }\end{array}$ & & \\
\hline
\end{tabular}

19a. NAME OF RESPONSIBLE PERSON STI Help Desk (email:help@sti.nasa.gov) 19b. TELEPHONE NUMBER (include area code) 443-757-5802 

